\title{
Redaktionens introduktion til Joseph Vogl: Markedets idyl
}

Joseph Vogl (f. 1957) er professor i litteratur- og kulturvidenskab ved Humboldt Universitet i Berlin og gæsteprofessor på Princeton University. Hans akademiske arbejde har de seneste år især omhandlet økonomisk teori og historie set fra et idé- kultur- og litteraturhistorisk perspektiv. Hans disputats Kalkül und Leidenschaft: Poetik des Ökonomischen Menschen (2006) undersøger i dette perspektiv homo economicus' fødsel og udvikling fra det 17. til det 19. århundrede. Das Gespenst des Kapitals (2010) leverer en kritisk analyse af den liberale doktrin om markedets rationalitet i lyset af den seneste finanskrise. I sin seneste bog, Der Souveränitätseffekt (2015) fortsætter Vogl den kritiske analyse, nu med særligt henblik på de politiske konsekvenser af den stadig tættere alliance mellem staten og markedet.

Det følgende er en oversættelse af andet kapitel i Das Gespenst des Kapitals. Der er tale om en idéhistorisk fremstilling af fremkomsten af en moderne, liberal markedsideologi. Vogl indleder kapitlet med at nævne det, han kalder en oikodicé. Begrebet er blevet lanceret i det foregående kapitel og dækker over det, Vogl mener, er en slags økonomisk udgave af det teologiske teodicé-begreb. En teodicé er som bekendt et forsøg på at forklare, hvorfor en god gud kan tillade, at verden er ond. En oikodicé er parallelt hermed en økonomisk doktrin om, at markedet dybest set er velordnet, fornuftigt og retfærdigt, selvom det på overfladen kan synes kaotisk og tilfældigt.

Vi håber med denne oversættelse at have givet flere lyst til at engagere sig i Joseph Vogls værk. En mere fyldig introduktion til det på dansk kan man finde online i Anders Engberg-Pedersens oversigtsartikel, "Kapitalens fiktion" i Salon 55. Das Gespenst des Kapitals er desuden oversat til engelsk under titlen The Specter of Capital (Stanford University Press, 2015). 